\title{
FAKTOR-FAKTOR YANG DAPAT MEMPERTAHANKAN NILAI-NILAI DALAM PROSES POLA ASUH
}

\author{
Roro Sri Hariyani \\ Kepala SMKN 3 Karang Baru Aceh Tamiang \\ rorosriharyani12@gmail.com
}

\begin{abstract}
Abstrak
Artikel ini merupakan hasil penelitian yang menjelaskan faktor-faktor yang dapat mempertahankan pola asuh pada anak. Penelitian ini merupakan penelitian kualitatif. Pengumpulan data dilakukan dengan menggunakan teknik observasi langsung, wawancara, serta studi literatur. Hasil penelitian menjelaskan bahwa ada beberapa faktor yang dapat mempertahankan nilai-nilai dalam proses pola asuh yaitu hubungan anak dengan orangtua dan keluarga luasnya, upaya orangtua dalam mempertahankan nilai-nilai dalam pola asuh, dan faktor agama Islam.
\end{abstract}

Kata Kunci: Pola Asuh, Nilai-Nilai, Orangtua, Keluarga Luas, Agama Islam

\section{PENDAHULUAN}

Sistem sosial merupakan wujud dari nilai-nilai budaya yang keseluruhannya berpengaruh terhadap pola asuh suatu suku. Nilai-nilai budaya tersebut tentunya merupakan bagian dari kebudayaan yang hidup pada masyarakat Tamiang. Oleh karena itu populasi dalam penelitian ini adalah penggambaran tentang keadaan individu dalam suatu keadaan dan gejala tertentu dari beberapa kebiasaan yang dijalankan oleh kelompok budaya etnik Tamiang.

John Dewey (Benedict,1962: 16) mengatakan bahwa riwayat hidup individu terutama sekali ialah penyesuaian diri kepada pola-pola dan ukuran-ukuran, yang turun temurun ada dalam masyarakatnya. Sejak saat ia dilahirkan, adat kebiasaan lingkungan tempat ia dilahirkan menentukan pengalaman dan kelakuannya. Menjelang waktu ia mulai bicara, ia telah merupakan hasil kecil daripada kebudayaannya dan bila sudah dewasa dan sudah bisa ikut serta dalam kegiatan-kegiatan masyarakatnya, maka adat kebiasaan-kebiasaannya, kepercayaan dan larangan-larangan lingkungannya merupakan pula adat kebiasaannya, kepercayaannya dan larangannya. Adapun yang menjadi sampel dalam penelitian ini adalah penduduk desa Sekrak dan Paya udang yang merupakan desa mayoritas etnik Tamiang.

Pola asuh menjadi bagian penting dalam kehidupan individu. Dalam proses belajar individu terhadap nilai-nilai yang berlaku di masyarakatmya, pola asuh menjadi salah satu bagiannya.

Orangtua menjadi agen sosialisasi yang pertama dalam proses belajar individu tentang nilai-nilai dalam masyarakat.

Individu pada masa kecilnya diibaratkan seperti kertas putih. Tulisan pertama yang akan ada di dalamnya berasal dari pengalaman pertama dalam proses belajar tentang nilai-nilai yang dimulai dari bayi.

Karakter dan kepribadian anak terbentuk memiliki kaitan erat dengan pola asuh yang diperolehnya dalam keluarga. Setiap individu, kelompok, maupun etnik memiliki pola-pola tersendiri dalam mengasuh anak. Pola-pola asuh ini yang membentuk masing-masing individu menjadi pribadi dalam masyarakat.

Perbedaan-perbedaan pola asuh merupakan implikasi dari perbedaan pola hidup setiap etnik tersebut. Perbedaan pola hidup, cara pandang, sistem budaya yang berlaku merupakan faktor yang mewarnai perbedaan itu.

Pola asuh merupakan proses interaksi antara anak dan orang tua dalam kehidupan sehari-hari. Pengasuhan berarti orang tua melakukan proses mendidik, membimbing dan mendisiplinkan serta melindungi anak untuk mencapai tingkat kedewasaan sesuai dengan norma-norma yang ada dalam masyarakat. Sehingga pola asuh dapat diartikan sebagai suatu cara yang di pakai atau di terapkan dalam menjaga, merawat, dan mendidik anak agar dapat berdiri sendiri.

Kepribadian anak setelah menjadi dewasa berkaitan dengan bentuk pola asuh yang diterima dari orang tua. Ciri-ciri dan unsur-unsur watak seorang individu dewasa sudah diletakkan benih-benihnya ke dalam jiwa seorang individu sejak sangat awal, yaitu pada saat ia masih kanak-kanak. Kebiasaan-kebiasaan yang dilakukan waktu kecil seperti cara makan, kebersihan, disiplin, diajar main dan bergaul dengan orang lain dan sebagainya menentukan kepribadian individu saat dewasa. Proses pengasuhan meliputi pola pendidikan, sopan santun, membentuk latihan-latihan, tanggung jawab dan sebagainya. Sehingga peran orang tua sangat penting, karena langsung menentukan sikap anak serta tindakkannya kemudian hari.

Pola asuh dapat menghasilkan individu-individu yang sesuai dengan harapan masyarakat. Hal tersebut dimungkinkan terjadi bila nilai-nilai selama proses pola asuh dapat bertahan dalam kehidupan individu.

Berdasarkan penjelasan di atas maka rumusan permasalahan dalam artikel ini adalah faktor-faktor apa saja yang dapat mempertahankan nilai-nilai dalam proses pola asuh? 


\section{METODE PENELITIAN}

Penelitian ini adalah penelitian kualitatif dengan tujuan mendeskripsikan faktor-faktor yang dapat mempertahankan pola asuh anak. Kata "kualitatif" menekankan kepada proses dan makna dengan menganalisis dan memahami pola dan proses sosial masyarakat, yang diakui tidak akan dapat diukur dan diuji secara tepat. Data utama penelitian ini adalah data kualitatif yang diperoleh melalui wawancara terhadap informan, baik informan kunci maupun bukan, mulai dari penduduk desa, pemerintahan swasta, maupun Lembaga Swadaya Masyarakat.

Pendekatan yang digunakan adalah hubungan lansung di tempat dimana peneliti tinggal bersama masyarakat yang diteliti, atau mendekati suatu masyarakat sebagai suatu sistem sosial yang terpadu. Dengan demikian penelitian ini dilakukan intensif dan berskala kecil, peneliti dapat mengikuti arus kehidupan sosial masyarakat di lokasi penelitian. Dalam pendekatan seperti ini peneliti tidak hanya mengumpulkan informasi tentang hal yang dipercayai, diyakini dan bagaimana mereka bertindak tetapi melihat bagaimana semua itu dikukuhkan dalam kehidupan sehari-hari (Fox, 1978:5).

\section{HASIL DAN PEMBAHASAN}

\section{Faktor Hubungan anak dan orang tua}

Hubungan anak dan orangtua dapat dilihat melalui pembagian kerja. Membahas pembagian kerja, berdasarkan observasi dan wawancara dengan ibu Aisyah $^{1}$, antara anak laki-laki dengan perempuan, beliau menyatakan bahwa ada perbedaan. Kepada anak lakilakinya sibapak berkewajiban mendidik anak bekerja untuk pribadi seperti berbelang, berhuma, membuat kebun, dan segala keperluan rumah tangga. Sedangkan untuk anak perempuan disediakan alat dan bahan untuk kerja tangan seperti bahan anyaman, kerawang, dan jahit menjahit juga pekerjaan didapur. Kalau ada kemungkinan atau kampung terdekat mengerjakan (pesta kawin atau seumpama), pemuda dan pemudinya disuruh menyamai kerja itu sampai selesai, dengan pesan agar supaya memperhatikan pelaksanaan adat resam kanun yang dilaksanakan dalam upacara dimaksud, untuk diresapi dan diingat sebagai ilmu pengetahuan.

Apabila kedapatan tingkah laku yang mungkin membawa akibat buruk, segera siibu menyampaikan kepada sibapak maka sibapaklah yang bertindak secara bijaksana. Ibu-ibu pada etnis Tamiang sangat lemah lembut dalam mendidik anak-anaknya, segala persoalan selalu mereka limpahkan kebapak atau bekerja sama dengan bapak/suami dalam memecahkan masalahmasakah anak-anaknya. Siibu senantiasa mengamatamati segala tingkah laku anaknya serta memberi nasehat dan petuah.

Hubungan antara saudara laki-laki dan perempuan sangat harmonis dalam etnis Tamiang. Antar laki-laki dan perempuan saling menghargai dan menghormati. Dimana siadik menghormati siabang, dan siabang menyayangi adiknya, begitu juga terhadap

${ }^{1}$ Salah satu ibu rumah tangga yang bekerja sebagai guru. Ibu Aisyah tinggal di desa Sekerak saudara perempuan mereka sangat melindungi sesuai dengan perintah agama. Hal ini diajarkan kepada anakanak etnik Tamiang sejak mereka berusia 2 atau 3 tahun. Sebagaimana hasil wawancara dengan bapak Syarifuddin Ismail ${ }^{2}$ yang menyatakan sebagai berikut: "Anak-anak Tamiang sejak umur umur 2 atau 3 tahunan sudah dikenalkan dan diajarkan kepada mereka tentang adat istiadat Tamiang, tentang kesopanan dan akhlak yang baik yang sejalan dengan agama". Dalam kelompok etnis Tamiang dikenal beberapa panggilan dalam hubungan pertalian darah dalam keluarga. Istilah-istilah tersebut diklasifikasikan berdasarkan tingkatan atau struktur anggota keluarga. Dalam garis hubungan masyarakat Tamiang mengadopsi system bilateral, yang artinya menghitung garis keturunan berdasarkan ayah dan ibu.

Hubungan anak dalam keluarga sangat jelas dilihat dari struktur yang ada di atas. Posisi anak dalam keluarga ditunjukkan melalui istilah-istilah pemanggilan yang terdapat pada tradisi Tamiang. Sejak kecil anak etnis Tamiang sangat dekat dengan keluarga mereka. anak-anak tersebut juga diberikan tugas dan tanggung jawab berdasarkan jenis kelaminnya. Pemberian tanggung jawab kepada anak-anak yaitu dengan membiasakan atau melibatkan mereka dalam berbagai aktivitas dalam rumah tangga.

Pembagian pekerjaan ini berkaitan dengan cara pengasuhan orang tua. Karena dengan cara ini orang tua memperkenalkan tanggung jawab, sehingga menjadi bekal keterampiannya di masa mendatang. Hal ini juga terkadang dihubungkan dengan perilaku anak. Melalui pembagian tugas ini juga anak-anak menunjukkan keikut sertaannya dalam aktiviatas-aktivitas keluarga dan membantu meringankan beban orang tua mereka. Hubungan antara orang tua dengan anaknya mencerminkan suatu keharmonisan, dan ini dapat mempengaruhi perilaku anak dari mulai kecil hingga anak dewasa. Sebuah keluarga yang memiliki beberapa orang anak, biasanya memiliki cara-cara tertentu sehingga setiap anak tidak ada yang merasa dibedakan dengan saudaranya sendiri. Selain itu setiap anak sejak masih kecil sudah diberikan tanggung jawab mengerjakan pekerjaan rumah seperti mencuci piring, menyapu halaman, menyapu rumah, membereskan tempat tidur, dan lain-lain.

Tabel. Istilah penyebutan atau sapaan dalam keluarga etnis Tamiang

\begin{tabular}{|c|c|c||}
\hline $\begin{array}{c}\text { Urutan } \\
\text { Kelahiran }\end{array}$ & $\begin{array}{c}\text { Istilah } \\
\text { Penyebutan }\end{array}$ & $\begin{array}{c}\text { Istilah } \\
\text { Sapaan }\end{array}$ \\
\hline \hline Anak ke 1 & Ulong & Yong \\
\hline \hline Anak ke 2 & Ngah & Ngah \\
\hline \hline Anak ke 3 & Alang & Ayang \\
\hline \hline Anak ke 4 & Uteh & Uteh \\
\hline \hline Anak ke 5 & Andak & Ndak \\
\hline Amak ke 6 & Uda & Uda \\
\hline Anak ke 7 & Itam & Tam \\
\hline
\end{tabular}

${ }^{2}$ Ketua Majelis Pertimbangan Pendidikan 


\begin{tabular}{|c|c||c|}
\hline Anak ke 8 & Acit & Cit \\
\hline \hline Anak ke 9 & Uncu & Ncu \\
\hline
\end{tabular}

Pembagian pekerjaan rumah antara anak lakilaki dan perempuan hanya dibedakan berdasarkan konsep lokal saja, artinya disini bahwa anak perempuan biasanya mendominasi pekerjaan dalam ruang lingkup rumah tangga seperti menyapu, mencuci piring, memasak, dan lain-lain. Sedangkan anak laki-laki biasanya tidak terlalu dibebankan pada pekerjaan-pekerjaan rumah tangga. Berbeda pada kasus pembagian kerja antara anak perempuan yang kecil dan adik perempuannya.

Pembagian pekerjaan berdasarkan umur ini diklasifikasikan berdasarkan tingkat kerumitan pekerjaan yang akan dijalani. Misalnya seperti anak-anak ibu Aton, menurut penuturan ibu tersebut biasanya pekerjaan rumah dibagi berdasarkan umur anak, biasanya anak yang paling besar mendapatkan pekerjaan yang lebih banyak dan lebih berat, sedangkan anak yang lebih muda (adik) mendapatkan pekerjaan yang lebih sedikit dan lebih ringan. Jenis pekerjaan rumah si kakak seperti mencuci piring, menyapu rumah dan juga menjaga adiknya. Sedangkan si adik biasanya mendapat pekerjaan membereskan tempat tidurnya, menyiram bunga dan sering disuruh ibunya ke warung untuk membeli sesuatu.

Pembagian kerja berdasarkan jenis kelamin dapat dilihat dari pekerjaan yang dilakukan antara anak laki-laki dan anak perempuan. Biasanya anak laki-laki mendapatkan pekerjaan yang lebih berat dari pada anak perempuan. Ini terjadi pada anak-anak ibu Zainab ${ }^{3}$ dimana anak laki-lakinya diberikan tugas mengisi air dan mengambil air ke tempat penampungan air, kemudian biasanya membantu bapaknya ke ladang. Anak perempuan biasanya tugasnya membereskan rumah seperti cuci piring, menyapu, dan membantu ibu di rumah. Anak laki-laki banyak membantu ayahnya di ladang dan anak perempuan banyak membantu ibunya di rumah. Menurut pengakuan ibu Zainab yang memiliki 6 orang anak ini bahwa dia merasa sangat dibantu oleh anak-anaknya, karena mereka semua mengerjakan pekerjaan rumah.

Bagi anak-anak ini pembagian kerja ini juga terkadang menimbulkan pertengkaran-pertengkaran antara kakak dan adik. Meskipun terkadang anak-anak ini tidak mutlak harus mengerjakan semua pekerjaan tersebut. Konflik yang berupa pertengkaran ini sering terjadi pada kakak dan adik, kakak yang punya pekerjaan lebih banyak dari pada adiknya sering mengeluh dan marah-marah mengerjakannya apalagi bila ia melihat adiknya hanya bermain-main. Kejadian lain yang membuat mereka bertengkar karena si adik terkadang melakukan pekerjaannya tidak maksimal, sering hasil pekerjaannya tidak bersih. Ini dapat dilihat dari kerapian ketika membereskan tempat tidur dan kamar, sewaktu adiknya membersihkan kamar ada barang kakaknya yang tidak kelihatan maka ini akan menimbulkan keributan

${ }^{3}$ Seorang Ibu rumah tangga yang memiliki enam orang anak. Ibu ini adalah salah satu warga etnik Tamiang yang tinggal di desa Paya Udang. dirumah. Biasanya salah satu dari mereka pasti ada yang menangis. Pertengkaran lebih sering terjadi antara anak perempuan, sedangkan pada anak laki-laki dan perempuan yang bersaudara tidak terlalu sering terjadi.

Biasanya apabila sudah bertengkar seperti itu maka tidak ada diantara mereka yang mau mengerjakan tugas dan biasanya ibunya yang marah-marah. Hal ini tidaklah berlangsung terlalu lama, apalagi mereka kemudian diizinkan bermain. Anak laki-laki jarang sekali bertengkar hanya karena pekerjaan rumah. Tetapi pertengkaran terjadi ketika ada perebutan mainan antara sesama saudara lelakinya. Selain karena mainan, biasanya yang dipertengkarkan masalah pekerjaan membantu bapaknya ke ladang. Biasanya bila bapaknya sudah marah maka mereka tidak akan ada lagi yang berani membantah karena mereka sangat takut pada bapaknya dari pada pada ibunya. Walaupun mereka bertengkar tugas mereka tetap juga mereka kerjakan dengan baik dan pertengkaran ini tidak berlangsung lama, beberapa jam kemudian biasanya langsung baikan lagi.

Bila anak-anak tidak mengerjakan tugas rumahnya maka ibu atau pun bapaknya akan marah. Biasanya ibu akan bilang " tidak usah kerjakan kerjaanmu nanti tidak akan ibu belikan baju, atau mainan sama kamu". Biasanya kalau sudah dibilang begitu pasti anak-anak takut dan cepat-cepat mengerjakan kerjaannya. Atau hal lain yang dikatakan seperti "tidak usah kerjakan nanti ibu kurung dikamar mandi" terkadang ibu mendiamkan saja tanda sudah amat marah. Ini dilakukan bila sudah tidak bisa lagi diberitahu atau dinasehati dan apabila mereka jadi bertengkar hanya karena tugas rumah mereka. Biasanya anak-anak tidak mau mengerjakan tugas rumahnya dengan alasan ada PR dari sekolah. Bila sudah ini alasannya maka ibu terkadang tidak akan menyuruh mereka dan mengerjakannya sendiri. ${ }^{4}$

Anak laki-laki dan perempuan sering bermain bersama setiap hari, ketika mereka bermain ada juga yang terlihat anak laki-laki ikut bermain masak-masakan dengan anak perempuan atau anak laki-laki ikut bermain boneka-bonekaan, begitu juga sebaliknya. Hal ini sesekali terlihat tetapi sebagai orang tua tidak ada tindakan yang berlebihan yang dilakukan, hanya bilang "mainlah apa yang punyamu, tidak boleh anak perempuan main kelereng (guli) dan sebaliknya". Bila sudah dibilang seperti itu maka ada juga yang langsung mamatuhi tetapi ada juga yang tidak, mungkin karena anak-anak menganggap hal seperti ini biasa. Mereka dapat bermain apa saja yang mungkin mereka inginkan. Biasanya bila terjadi seperti itu sudah menjadi hal biasa yang terlihat jadi bukan sesuatu kejanggalan.

Antara kakak dan adik juga sangat dekat, dengan jarak umur yang tidak terlalu jauh sehingga dapat tumbuh bersama. Ditambah lagi pengajaran dari orang tua untuk menghormati dan menyayangi kakak atau adik sendiri. Di Desa Payah Udang dan Desa Sekerak Kanan masih dijumpai keluarga yang memiliki banyak anak dan ada juga yang sedikit. Dijumpai juga antara kakak dan adik bertengkar ketika bermain memperebutkan mainan atau karena adik kalah bermain dengan kakaknya. Tetapi

\footnotetext{
${ }^{4}$ Wawancara dengan ibu Nur' Aini.
} 
biasanya sebentar saja mereka akan rujuk kembali dan bermain kembali. Inilah hubungan yang terlihat diantara keluarga etnis Tamiang yang masih dekat dan ini juga dipengaruhi oleh kondisi lingkungan sekitarnya, yang masih memegang adat istiadat Tamiang.

Penilaian terhadap sopan santun anak dapat dilihat dari sopan santun terhadap orang lain. Setiap orang tua menginginkan anaknya memiliki sopan santun yang baik kepada orang lain, membantu orang lain sehingga banyak orang yang suka dan menyayanginya. Biasanya bila si anak baik maka banyak orang yang suka padanya, dan biasanya mereka juga akan memuji ibunya. Ini sebuah kebanggaan bagi orang tua bila banyak orang yang sayang pada anaknya. Menurut ibu Khadijah ${ }^{5}$ bila anak berkelakuan baik dan menyenangkan hati orang maka terkadang diberi pujian melalui kata-kata, seperti "ini anak mamak yang baik budi selalu buat hati orang tua senang" ataupun diberi hadiah berupa mainan. Bila anak baik maka hadiah dan pujian tidak hanya datang dari orang tuanya tetapi juga dari orang yang dibuatnya senang.

Seorang anak sangat senang dipuji dan juga disayang oleh orang lain. Apalagi bila ketika dipuji ada temannya yang mendengar maka ini akan menjadi kebanggaan tersendiri bagi dia. Lebih lagi bila anak diberikan hadiah maka lebih besar pula rasa senangnya. Oleh karena itu maka si anak akan melakukan hal yang sama untuk menyenangkan hati orang dan mendapatkan hadiah. Menurut ibu Zainab memberikan pujian bagi si anak juga menjadi salah satu cara yang baik untuk mendidik anak menjadi lebih baik. Anak tidak boleh selalu dimarahi bila ia berbuat nakal, harusnya dia dinasehati dan diberitahu hal yang baik. Bila anak langsung dimarahi bisa-bisa anak menjadi trauma dan akan berbuat nakal terus. Sebagai orang Tamiang maka dari kecil anak-anak Tamiang sudah diajari sopan santun dan tata krama, ini tidak hanya diajarkan oleh orang tua tetapi juga dalam agama. Dari sejak kecil anak sudah diajarkan sholat dan mengaji oleh sebab itu ketika mengaji maka anak juga mendapatkan pelajaran agama. Dari situlah anak mendapat pelajaran agama dan membantunya menjadi anak yang baik, Walaupun ada juga anak menjadi anak yang nakal. Oleh sebab itu ilmu agama sangat penting bagi moral si anak.

Setiap anak adalah kebanggaan buat orang tuanya, setiap orang tua ingin anaknya membawa nama keluarganya. Sebagai salah satu contoh adalah etnik bangsa Batak, bagi orang Batak anak laki-laki pertama akan membawa marga bapaknya sehingga dari sejak kecil sudah diajari akan adat Batak itu sendiri. Tidak hanya etnik bangsa Batak yang demikian. Menurut bapak Syarifuddin Ismail ${ }^{6}$ etnis Tamiang juga demikian. Sejak kecil anak juga diajari adat istiadat Tamiang. Seorang anak Tamiang dikatakan sebagai anak Tamiang adalah dengan melihat dialek Tamiang yang tentunya berbeda dengan dialek Aceh (karena berbaur dengan etnis Aceh) ketika berbicara dengan orang lain. Seorang anak

${ }^{5}$ Salah satu warga etnik Tamiang yang tinggal di desa Kota Lintang

${ }^{6}$ Ketua Majelis Pertimbangan Pendidikan Tamiang dikatakan anak Tamiang adalah jika anak juga telah mengerti dan menerapkan budaya-budaya Tamiang. Biasanya setiap anak dari mulai beranjak remaja telah diajarkan budaya-budaya Tamiang, yang paling terlihat adalah dari dialek berbicaranya.

Selain itu, terkait dengan hubungan orang tua dengan anak, terutama yang berhubungan dengan model pengasuhan, maka para orang tua etnik Tamiang pada umumnya menganut pola asuh demokratis. Orang tua memberikan kebebasan kepada anak untuk berkreasi dan bereksplorasi. Namun demikian, orang tua memberikan batasan-batasan dalam arti otoriter terutama menyangkut hal-hal adat istiadat dan agama. Misalnya, orang tua sangat menekankan kepada anak dalam mengaji alQur'an, menjaga kesopanan, dan lain-lain.

\section{Faktor Hubungan Anak dalam Keluarga Luas}

Pada masyarakat etnis Tamiang dari mulai turun tanah anak sudah diajarkan untuk bersosialisasi, selain dengan kerabat dekat ayah dan ibu juga para tetangga. Biasanya setelah turun tanah pada sore hari selesai mandi sianak oleh neneknya dibawakan(ditandangkan) atau dibawa jalan-jalan keluar rumah. Ditandangkan biasanya kerumah keluarga atau jiran tetangga yang terdekat dan terletak disebelah hulu. Keluarga yang ditandangi atau dikinjungi menyambut anak yang datang tersebut dengan resam mencicipi, kalau laki-laki dengan garam dan kalau anak perempuan dengan gula.

Ketika sianak hendak dibawa pulang, ibu rumah yang ditandangi tadi haruslah memberikan hadiah (memanja jametook) kepada anak tersebut. Kalau tidak ada uang boleh juga sebutir telur ayam kalau inipun tidak ada haruslah disambilkan bambu atap lalu di genggam ketangan anak itu dengan mengucapkan sepatah kata "ingatlah yang ada, janganlah kau lupakan andung(makjik) doaku menyertaimu”.

Dalam hal resam mencicipi bayi ini, terkadang orang tua menyerahkan atau meminta orang yang dianggap alim, atau imam kampung yang dipandang alim. Hal ini dimaksudkan, agar kelak si anak menjadi orang alim juga, terpandang dan baik budi pekertinya. Upacara nyecapi ini terkadang juga dimulai dengan mengucapkan "Bismillahirrahmanirrahim, biar manih lidah, panjang umor, mudah rejeki, bergune kak masyarakat, biar taat beribadah". Selain itu juga, adat ini bertujuan untuk member rasa kepada bayi agar nanti tidak canggung hidup dalam masyarakat dan tidak malas bekerja.

Pada dasarnya, proses resam mencicipi bayi ini adalah sebuah pengharapan dari orang tua kepada anaknya kelak menjadi orang yang dapat dibanggakan oleh orang tuanya, menjadi anak yang berbudi baik dan rajin. Proses pengharapan inilah kemudian dikemas dalam suatu proses adat istiadat.

Kepercayaan di Tamiang dalam hal menandangkan anak, mula pertama haruslah kearah hulu dari rumahnya, kemudian seterusnya barulah boleh ditandangkan kearah-arah yang lain, setidaknya sampai bayi tersebut berumur enam bulan. Setiap rumah yang mendapat tandangan (kunjungan) anak sewaktu 
pulangnya haruslah dihadiahi (digenggamkan) kedalam tangannya, jangan sampai ia pulang kosong takut anak tersebut berputus asa, karena keyakinan orang-orang Tamiang bahwa anak itu selalu disertai oleh malaikat.

Untuk menandang bayi sesudah yang pertama, biasanya sinenek bersama anak dan anak menantunya silih berganti mengunjungi rumah-rumah keluarganya dan jiran terdekat. Kesemua pembiasaan yang dilakukan pada anak dari mulai sejak bayi pada lingkungan keluarganya dan tetangganya menjadikan anak-anak Tamiang dekat dengan keluarga dan juga jiran tetangga, serta lingkungan masyarakat tempat tinggalnya. Hingga ketika mereka menginjak usia remaja dan dewasa hal ini menjadi sebuah tradisi, juga terjalin hubungan yang akrab.

Dalam menanamkan nilai-nilai dan pendidikan agama, para orang tua menurut bapak Syarifuddin Ismail ${ }^{7}$ memasukkan anak-anaknya sejak usia 4-7 tahun untuk mengaji, selain belajar ke sekolah. Adalah suatu keaiban apabila sianak telah tahu malu tapi belum diserahkan mengaji pada imam kampung/meunasah. Pada jaman dahulu sepanjang resam adat Tamiang menyerahkan anak mengaji haruslah menyediakan:

1. Pulut kuning + ayam panggang + pisang raja seikat + telur ayam rebus sebutir

2. Beretih sepinggan

3. Rotan sega sepanjang lebih kurang 1 hasta, separuh ujungnya dibelah tujuh pangakalnya dan ditajami

4. Surat Jus Amma beserta rehalnya

5. Sirih sejorong

Syarat-syarat itu akan berbeda bila anak chatab juz Amma juga chatab Al-quran. Dimana tentunya orang tua akan kembali membawa syarat-syarat yang ditentukan pada imam kampung.

Seorang anak laki-laki dianggap sudah dewasa ketika dia sudah "akil baliq", pada masa ini seorang anak laki-laki dianggap sudah dapat memikul tanggung jawab yang lebih besar dari keluarga. Ketika anak sudah bekerja maka tanggung jawab itu lebih besar diberikan orang tua. Karena dianggap sudah memiliki kedewasaan dan sudah dapat memimpin di dalam sebuah keluarga. Maka tanggung jawab sang anak juga semakin bertambah. Tanggung jawab kepada keluarga akan lebih terlihat ketika orang tuanya sudah tidak dapat lagi bekerja maka kebutuhan keluarga ditanggung oleh anaknya.

Pada usia 13 sampai 14 tahun anak - anak di Desa Paya Udang dan Desa Sekerak kanan sudah terlihat ikut bekerja membantu orang tuanya sepulang sekolah, itupun jika anak-anak sekolah tapi jika anak-anak tidak sekolah maka mereka sudah ikut bekerja sejak pagi hari. Biasanya pekerjaan yang mereka lakukan adalah mengambil pasir di sungai ataupun mencari ikan. Bila mereka memiliki sawah ataupun ladang,anak-anak diajarkan untuk bekerja bersawah dan berladang. Jadi pada usia tertentu anak-anak sudah diajarkan kemandirian oleh orang tuanya ditambah lagi dengan tuntutan ekonomi di dalam keluarga. Anak laki-laki memiliki tanggung jawab yang lebih besar dalam

\footnotetext{
${ }^{7}$ Ketua majelis Pertimbangan Pendidikan Tamiang
}

keluarga sehingga sejak mulai beranjak remaja sudah ditanamkan nilai tanggung jawab tersebut.

Sedangkan anak perempuan pada tahap kedewasaan maka orang tua mulai memikirkan jodoh anaknya apalagi bila anak perempuannya tidak sekolah maka yang dipikirkan adalah jodoh anaknya. Ketika anak perempuannya sudah mulai didekati seorang laki-laki maka orang tua sudah menilai anaknya sudah beranjak dewasa dan sudah dapat menikah. Anak perempuan yang sudah bekerja juga dapat membantu orang tua memenuhi kebutuhan keluarga. Anak perempuan di Desa Paya Udang dan Sekerak Kanan banyak juga yang menikah di usia muda.

Istilah sapaan yang menjadi ciri khas pada orang etnis Tamiang selalu diajarkan kepada anak-anak mereka. Ini merupakan tradisi yang harus dilaksanakan dalam hubungan kekeluargaan. Istilah sapaan ini menjadi pengikat hubungan kekeluargaan mereka. Istilah sapaan dalam tradisi Tamiang tersebut juga mengekspresikan penghormatan dari orang yang muda kepada orang yang lebih tua.

Mengacu pada pandangan John W. M. Whiting Irvin L Child dkk dalam James Danandjaja (1989:10) terkait dengan pola pengasuhan anak, maka masyarakat etnik Tamiang, pada umumnya lebih cenderung pada beberapa pola asuh seperti;

1. Tingkah laku yang bersifat mempunyai rasa tanggung jawab (responsibility)

Pola asuh metode ini mengunggulkan sifat untuk menyelesaikan pekerjaan yang menjadi tugas pokoknya. Melakukan aktifitas sesuai dengan semestinya, tidak melakukan pekerjaannya berdasarkan kesenangan saja tanpa prosedur atau norma-norma yang ada dalam melakukan pola asuh terhadap anak, sehingga pekerjaan itu selesai sesuai dengan norma-norma yang berlaku. Dengan demikian optimalisasi dalam menanamkan norma-norma pola asuh sesuai dengan tanggung jawab terhadap apa yang dilakukannya.

Hal ini tampak pada bagaimana orang tua bertanggung jawab dalam mengasuh anakanak mereka. Sebagai contoh adalah bahwa orang tua etnik tamiang sangat memperhatikan kegiatan dan perilaku anak-anak mereka seharihari. Dalam hal pengasuhan anak mereka juga kurang memberikan kepercayaan kepada orang lain untuk mengasuh anaknya. Mereka lebih mengutamakan mengasuh anak mereka dengan sendirinya. Selain itu juga, pola pengasuhan model ini, terlihat dari bagaimana para orang tua etnik Tamiang mendidik anak-anak mereka untuk memiliki rasa tanggung jawab terhadap apapun yang mereka perbuat. Sebagai contoh, ketika anak disuruh untuk membersihkan rumah, maka mereka harus menyelesaikan pekerjaan tersebut. Ini sebagaimana yang disebutkan oleh Pak Sarmidin ${ }^{8}$ yang menyatakan bahwa jika

\footnotetext{
${ }^{8}$ Pak Sarmidin adalah Kepala Sekolah Dasar di Desa
} Sekerak Kanan. 
anak diamanahkan suatu pekerjaan, maka orang tua akan memberikan sanksi jika hal itu tidak dilakukannya. Hal ini menurut beliau dimaksudkan sebagai upaya menanamkan rasa tanggung jawab pada diri anak tersebut.

2. Tingkah laku yang bersifat ingin mencapai sesuatu yang lebih baik (achievement-oriented behavior)

Yaitu pola asuh yang menunjukkan bahwa perilaku yang ditampilkan lebih menonjol prestasi yang terbaik. Metode ini mengajarkan untuk senantiasa membudayakan prioritas yang lebih baik. Memberikan pola asuh tersebut dengan memberikan contoh-contoh sifat yang berupaya untuk mendapatkan yang terbaik dari yang lainnya. Berorientasi kepada perilaku yang lebih baik.

Pola ini tampak pada bagaimana para orang tua mendidik anak-anak mereka. Para orang tua selalu mengajarkan kepada anak-anak agar selalu memiliki sifat dan perilaku yang baik kepada orang lain. Hal ini menunjukkan bahwa ada upaya orang tua untuk senantiasa menonjolkan hal-hal yang lebih baik pada kehidupan.

3. Tingkah laku yang bersifat patuh pada orang tua atau pemimpin (obidience)

Pola ini mengajarkan kepada anak agar memahami posisi kehidupan dalam keluarga, memahami siapa yang harus di hormati dan disayangi dan siapa pula yang memiliki hak untuk mengayomi, memelihara, melindungi dan memberikan kasih sayang dan perhatian. Sehingga dengan posisi kedudukan ini memudahkan untuk menerapkan pola asuh kepada anak-anaknya. Karena dipahaminya siapa yang harus disayanginya dan di hormatinya. Selain itu metode ini menunjukkan siapa diantara keluarga itu lebih banyak mempengaruhi untuk dapat mencapai tujuan kehidupan keluarga. Berarti memahami siapa yang menjadi pemimpin dalam keluarga tersebut. Itu artinya orang tua lah yang harus diperhatikan perilakunya dalam memberikan pola asuh kepada anak-anaknya.

Salah satu bentuk yang mengindikasikan pola ini dalam pengasuhan anak Tamiang yaitu kuatnya adat Tamiang dalam mendidik anak-anak mereka dalam hal panggilan keluarga dan kepada orang yang lebih tua dari mereka. Selain itu, peran ayah dan ibu bisa dikatakan bukan peran yang paling utama dalam hal pengasuhan. Atok atau nenek dalam masyarakat Tamiang juga mempunyai kedudukan penting baik itu dalam hal pengasuhan anak, terutama dalam hal mengambil kebijakan keluarga terkait dengan masalah anak dalam keluarga. Hal ini sebagaimana yang diutarakan oleh Bapak Hasnan yang tinggal di desa Sekerak Kanan.
4. Tingkah laku yang bersifat gemar menolong orang lain yang sedang mengalami kesukaran (nurture).

Pola ini mengajarkan kepada anak untuk memiliki sifat perhatian kepada orang lain (Emphaty). Memahami apa yang dirasakan oleh orang lain, sehingga mendorong orang tersebut untuk membantu orang yang mengalami kesulitan.

Pola pengasuhan ini terlihat pada bagaimana orang tua senantiasa menanamkan rasa peduli terhadap sesama. Bagaimana orang tua selalu menanamkan rasa kepekaan sosial dan rasa berbagi dengan sesama. Misalnya, ketika anak dibelikan jajanan atau kue-kue ringan di saat ia ada bersama teman-temannya, maka orang tua selalu mengajarkan untuk memberi sebagian kepada teman bermainnya. Perbuatan ini tentunya merupakan upaya orang tua dalam menanamkan rasa kepedulian sosial kepada anak sejak dini.

Dilihat dari beberapa hal di atas, maka dapat disimpulkan bahwa ada empat hal yang sangat penting terkait dengan pembentuka karakter anak atnik Tamiang yang ditanamkan oleh orang tua yaitu;

1. Internalisasi nilai-nilai memiliki rasa tanggung jawab terhadap setiap yang dilakukan oleh anak dan yang diamanahkan kepadanya.

2. Pendidikan kepada anak tentang pentingnya perubahan diri untuk senantiasa menuju kepada segala sesuatu yang baik dalam segala hal.

3. Pembentukan karakter anak agar memiliki rasa hormat dan patuh kepada orang tua dan keluarga besar lainnya.

4. Penanaman nilai-nilai kepedulian sosial kepada anak, agar kelak anak menjadi orang yang peduli kepada orang lain, terutama mereka yang membutuhkan.

\section{Faktor Upaya Orangtua}

Di Desa Paya Udang dan Desa Sekerak Kanan terlihat bahwa anak yang menetap di desa bersama orang tuanya dan tidak melanjutkan sekolah ke luar kota akan lebih mengerti adat dan menerapkannya di keluarganya, ini dapat dibandingkan anak yang melanjutkan sekolah ke jenjang yang lebih tinggi misalnya kuliah yang banyak tidak mengerti lagi dengan adat Tamiang karena sudah berinteraksi dengan dunia luar. Yang lebih disayangkan lagi, anak-anak yang melanjutkan sekolah ke kota ataupun kuliah keluar daerah sudah tidak pandai lagi berbahasa Tamiang.

Upaya orang tua untuk memperkenalkan dan menerapkan nilai-nilai budaya Tamiang dengan cara mensosialisasikan budaya Tamiang kepada anakanaknya. Salah satu cara mensosialisasikan nilai-nilai budaya biasanya dilakukan orang tua dengan membawa anak ke acara-acara adat seperti ke pesta pernikahan, sunatan atau acara-acara tepung tawar. Upaya ini dilakukan agar anak dapat langsung melihat dan ketika melihat maka orang tua menjelaskan dan terkadang orang 
lain atau kerabat yang berada disekitar tempat pesta juga menjelaskan arti adat tersebut. Biasanya dijelaskan apa arti pantun yang didengar atau arti tepung tawar dan lainlain.

Tidak hanya pada saat ada acara adat saja orang menjelaskan tetapi juga ketika dirumah orang tua juga mau bercerita. Menurut ibu Salmah ${ }^{9}$ anak zaman sekarang tidak begitu tertarik dengan urusan adat, terkadang kalau orang tua sudah bercerita pun mereka banyak yang tidak berminat. Anak lebih suka cerita tentang hal-hal yang lebih modern. Sehingga ini mengakibatkan sedikit demi sedikit adat itu mulai tidak melekat dalam diri anak-anak Tamiang sekarang. Hal ini terlihat dari hanya beberapa orang saja anak muda yang bisa berpantun di Tamiang. Bila diajarkan mereka menganggap itu sudah tidak zamannya lagi, oleh sebab itu orang yang bisa berpantun dan dikenal banyak orang adalah Toek Yusuf. Bahkan anak-anak pak Yusuf pun tidak ada yang mahir berpantun seperti orang tuanya.

Ketika ada acara-acara yang berkaitan dengan upacara adat tertentu maka Pak Yusuf akan diundang untuk berpantun bahkan tidak hanya di Desa Paya Udang tetapi juga sampai ke daerah Langsa dan terkadang sampai ke Banda Aceh juga. Menurut Pak Yusuf seandainya anak muda sekarang mau belajar maka budaya berpantun pada orang Tamiang akan semakin berkembang dan menjadi kebanggaan bagi orang Tamiang. Tidak hanya berpantun dalam suatu upacara adat selalu terdapat tradisi marhaban. Kegiatan marhaban merupakan suatu upacara yang berkenaan dengan pemberkatan dan permohonan ridho dari Tuhan yang Maha Esa. Marhaban dilakukan dalam upacara perkawinan, mengayun anak, dan juga ketika menyambut tamu kehormatan.

Setiap orang tua memiliki tugas untuk selalu menjelaskan dan menerapkan adat istidat Tamiang sehingga tidak akan terhapus oleh zaman. Apabila tidak ada lagi upaya-upaya mensosialisasikan adat istiadat Tamiang kepada anak-anak, maka para orang tua mengkhawatirkan akan terjadinya pengikisan nilai-nilai budaya Tamiang pada anak-anak.

Saat ini saja ada beberapa hal yang sudah tidak lagi dijalankan oleh para generasi muda. Salah satunya adalah aturan terhadap pantangan-pantangan pada saat masa kehamilan juga tradisi kenduri pada saat perkawianan, kehamilan dan turun tanah. Jenis pantangan yang jarang dilaksanakan pada saat ini adalah sesuatu yang sangat berkaitan dengan nilai-nilai budaya Tamiang dan Islam yaitu mengaji. Dari hasil wawancara yang dilakukan oleh para ibu-ibu yang pernah mengalami masa kehamilan terungkap kebiasaan mengaji pada saat hamil sudah jarang dilaksanakan. Padahal para orang tua dahulu setiap selesai sholat maghrib mereka tetap mengaji. Pergeseran ini terjadi karena mobilitas para ibu-ibu yang saat ini telah banyak melakukan aktivitas di luar rumah. Sehingga ini mengakibatkan waktu luang yang seharusnya digunakan untuk mengaji beralih pada aktivitas yang lain. Sedangkan upacara-upacara pada

9 Salah satu tokoh wanita Tamiang. Sebagai ketua pelestarian adat Tamiang kenduri sering tidak dilaksanakan mengingat dana juga waktu. Hal ini mengakibatkan ketidak tahuan generasi muda akan resam adat yang ada.

Sikap para orang tua yang melakukan resistensi dan upaya untuk mempertahankan adat istiadat Tamiang ternyata tidak berpengaruh besar trehadap pengimplementasian adat istiadat Tamiang secara mutlak. Hal ini dikarenakan ada sebagaian orang yang menganggap bahwa tradisi yang berkaitan dengan pola asuh tidak lagi sesuai dengan kebutuhan mereka. Ada yang merasa tidak penting tetapi ada juga yang merasa penting. Merasa zaman yang sudah berbeda sehingga sebagian merasa pantangan itu tidaklah penting dilakukan.

Selain perbedaan pandangan pada setiap individu, faktor lain yang mempengaruhi adalah pendidikan, bagi ibu yang memiliki pendidikan yang lebih baik merasa pantangan-pantangan yang harus dilaksanakan pada saat kehamilan karena ia merasa bahwa terkadang ketentuan-ketentuan yang terdapat dalam nilai-nilai budaya yang berkaitan dengan pola asuh tidak rasional.

Ada orang tua yang marah apabila anaknya meremehkan wejangan-wejangan atau pantanganpantangan yang diberikan orang tua. Cara pandang orang tua untuk melegitimasi adat istiadat tersebut diungkapkan dengan kata-kata sebagai berikut "awas kualat nanti kalau tidak mendengar omongan orang tua" atau biasanya orang tua akan menasehati anaknya kembali dan menceritakan konsekuensi atau akibat yang dialami oleh orang yang melanggar pantangan berdasarkan pengalaman-pengalaman orang tuanya sebelumnya. Ada juga kata-kata yang mengimplementasikan suatu pengharapan agar suatu hal yang buruk tidak terjadi pada dirinya yaitu mengucapkan "jauh-jauhlah segala yang tidak baik".

Dari sini dapat dipahami bahwa faktor yang berperan sebagai resistensi terhadap penerapan dan pelestarian budaya adalah sikap dan peran orang tua yang memberikan pelajaran pemahaman tentang pentingnya adat istiadat dan budaya lokal. Para orang tua ini memberikan pengenalan terhadap budaya ini sejak anakanak masih usia dini.

\section{Faktor Agama Islam}

Aceh Tamiang merupakan wilayah Aceh yang berbatasan dengan daerah Langkat Sumatera Utara. Berhubung karena itu, sesuai dengan letak geografis daerah Aceh Tamiang dan sejarah asal - usul penduduknya, maka kebiasaan dalam prihidup suku dari masa kemasa walaupun bagian daerah ini adalah bagian Hukum Daerah Aceh umumnya namun terdapat ciri-ciri yang khusus dan adat istiadat yang spesifik yang di warisi oleh penduduknya turun temurun dan tetap dipelihara. Daerah Aceh Tamiang di domisilir oleh Etnis Melayu dan sering di sebut dengan Tamiang atau Aceh Tamiang.

Pengaruh agama Islam terhadap kehidupan Etnik Melayu sangat besar dan menjadi keputusan terakhir yang terpatri didalam jiwa mereka. Sehingga muncul penafsiran bahwa masuk Melayu berarti masuk 
Islam. Ciri keislaman etnis Melayu sepenuhnya tampak dari penggunaan nama yang mereka gunakan dimana pada umumnya mengandung unsur Islam.

Kerajaan Islam Tamiang mulai berdiri pada tahun 1130 dibawah pemerintahan raja Muda Sedia ( 1130-1352 ) dengan sistem pemerintahan ber-balai dibantu oleh Mangkubumi ( Raja Muda Sedianu ) dengan Guru Besar Tu Ampun Tuan, beserta para Empat Besar Kerajaan ( Ndatu Empat Besar ) yang masing masing juga sebagai kepala-kepala pemerintahan bawahan yang sifatnya langsung dengan ketentuan harus berpegang teguh kepada " Kase Tuha"

$$
\begin{array}{ll}
\text { - } & \text { Adat dipangku } \\
\text { - } & \text { Sjarak dijenjang } \\
\text { - } & \text { Resam dijalin } \\
\text { - } & \text { Kanun diatur }
\end{array}
$$

Wilayah Tamiang berada pada ketinggian $0-25$ meter dari permukaan laut. Setelah otonomi daerah terjadi pemekaran wilayah tanggal 11 Maret 2002, Tamiang disahkan menjadi sebuah Kabupaten (Panitia Persiapan Kabupaten Aceh Tamiang 2000).

Suku bangsa Tamiang mendiami tujuh kecamatan, yaitu Kecamatan Karang Baru, Kecamatan Kejuruan Muda, Kecamatan Kuala Simpang, Kecamatan Seruway, Kecamatan Tamiang Hulu, Kecamatan Bendahara, dan Kecamatan Rantau.Setelah Tamiang disyahkan menjadi Kabupaten pada tanggal 11 Maret 2002, Kecamatan Manyak Payed yang pusat pemerintahannya Tualang Cut bergabung kedalam wilayah Tamiang, dan berbatasan dengan Kecamatan Langsa Timur, dengan demikian Kabupaten Aceh Tamiang menjadi 8 (delapan) Kecamatan.

Berdasarkan legenda sejarah bahwa Raja Tamiang pertama adalah Tan Penok yang konon cerita legendanya memungut seorang anak dari rumpun bambu dan diberinya nama Pucok Suloh kemudian setelah dewasa diangkat menjadi Raja Tamiang (11901256).Setelah Raja Pujok Suloh wafat digantikan oleh anaknya Raja Pepala (Po Pala tahun 1256-1278). Dan setelah wafatnya Raja Pepala ini di ganti oleh Raja Podewangga (1278-1300 M). Perkembangan kerajaan dimasa pemerintahan beberapa Raja ini masih belum dapat diketahui hanya sebatas mengetahui silsilahnya saja. Penerus kerajaan ini ialah Raja Dinok di mana pada masa pemerinyahannya ini terjadi penyerangan dari kerajaan Samudra Pasai atas perintah Sultan Mahmud Malikuzzahir (Raja Mahmuddin atau Ahmad Bahiansyah Sultan Samudra Pasai (1326-1345 M ). Sejak penguasaan inilah Islam di masukkan ke Tamiang. Pengganti Raja Dinok yang diangkat oleh Raja Samudra Pasai ialah Raja Muda Sedia sebagai Raja Islam Tamiang pertama. Sejak pemerintahan Raja Muda Sedia inilah ajaran Islam terus berkembang di Tamiang dan di perdalam oleh orangorang Tamiang ( Wan Diman,2003:12).

Pengaruh agama Islam terhadap kehidupan etnik Melayu Tamiang ini sangat besar sama seperti suku Aceh dan menjadi keputuasan terakhir yang terpatri di dalam jiwa mereka. Sehingga muncul penafsiran bahwa masuk Melayu berarti masuk Islam. Ciri keislaman etnik Tamiang sepenuhnya tampak dari.penggunaan nama yang mereka gunakan dimana pada umumnya mengandung unsur Islam.

Etnik Tamiang umumnya hidup dari hasil sawah mereka, mengerjakan ladang yang tidak jauh dari rumah. Pekerjaan berladang merupakan pekerjaan sambilan yang dikerjakan dengan mencangkul tanah, dan ditanam dengan berbagai macam tanaman seperti padi darat, cabe, jagung dan tanaman palawija.

Nelayan merupakan mata pencaharian bagi suku perkauman Tamiang yang bertempat tinggal dipinggiran sungai dan di muara-muara yang menjorok kelaut.

Kelompok etnik adalah suatu populasi yang secara biologis mampu berkembangbiak dan bertahan, mempunyai nilai-nilai budaya yang sama dan sadar akan kebersamaan dalam bentuk budaya, membentuk jaringan komunikasi dan interaksi sendiri, menentukan sendiri ciri kelompoknya, yang diterima oleh kelompok lain dan dapat dibedakan dari kelompok populasi kelompok lain (Barth, 1998:1).

Agama Islam lebih menonjol dalam segala bentuk dan manifestasinya dalam masyarakat yang seirama dengan perlakuan adat. Sehingga terlihat bahwa agama Islam telah mempengaruhi sifat kekeluargaan, seperti perkawinan, harta waris dan kematian. Keterikatan agama ini juga mempengaruhi dalam menentukan pendidikan, banyak masyarakat etnik Tamiang memasukkan anaknya pada sekolah-sekolah agama, kalaupun mereka sekolah disekolah umum namun pada siang hari atau sore hari bahkan malam hari mereka harus dididik dalam pelajaran agama.

\section{PENUTUP}

Pola asuh menjadi kunci mempertahankan nilainilai positif dari tradisi masyarakat tertentu. Untuk itu pola asuh sebagai bagian penting dalam mempertahankan nilai positif sebagai jati diri suatu masyarakat harus dipertahankan.

Beberapa fahtor yang dapat mempertahankan nilainilai positif masyarakat melalui pola asuh yaitu hubungan anak dan orang tua, hubungan anak dan keluarga luas, faktor upaya orangtua untuk mempertahankan tradisi, dan faktor agama Islam yang dianut.

\section{DAFTAR PUSTAKA}

Barth, Fredrik,1988. Kelompok Etnik Dan Batasannya. Jakarta: UI Press

Benedict, Ruth, 1962. Pola-pola Kebudayaan. Jakarta:PT Pustaka Rakyat

Berry. W .Jhon dkk, 1999. Psikologi Antar Budaya, Jakarta: Eralangga

Danandjaja, James. 1989. Kebudayaan Petani Desa Trunyan di Bali. Jakarta: UI Press.

Danny I. Yatim-Irwanto, Kepribadian Keluarga Narkotika, (Jakarta : Arcan, 1991), Cet.

EMTAS, 2006. Peradapan Aceh. Banda Aceh:Yayasan Busafat.

Fox, Richard.1978. " Antropologi dan Kota ” Berita Antropologi. Nomor 34. 
Geerz Clifford. 1976. Involusi Pertanian. Ahli Bahasa S.Supomo. Jakarta : Bhratara Karya Aksara.

Harley, 2008. Mukim Masa ke Masa.Banda Aceh: JKMA

http://health.kompas.com/read/2011/01/14/11561472/Me nyimak.Pola.Asuh.Anak.di.Negara.Lain\#

http://paradigmaindonesia.wordpress.com/2011/09/17/psi kologi-perkembangan-perspektif-lintas-budayatentang-pola-asuh/

Ihromi, T.O 1987. Pokok-pokok Antropologi Budaya. Jakarta: Gramedia

In Figures Tamiang Aceh, 2006. Aceh Tamiang Dalam Angka. Badan Pusat Statistik, Corporated Wiht

Kartono, 1986. Metodologi Penelitian Pendidikan . Jakarta: PT Bumi Aksara

Ke-1, h. 94

Koentjaraningrat, 1979. Manusia Dan Kebudayaan di Indonesia. Jakarta: Djambatan.

Mahmunarrasjid, 1973. Monografi Aceh Timur. Langsa: Set Da Kap Aceh Timur.

Martin, CA \& KK. Colbert (1997). Parenting: a Life Span Perspective. New York: The McGraw-Hill Companies, Inc

Mead, Margaret. 1988. Taruna Samoa ( Remaja dan Kehidupan Seks Dalam Kebudayaan Primitif ) Suatu Penelitian Antropologi Budaya. Jakarta: Bharatara

Miles, B. Matthew dan Huberman, A. Michael. (1992). Analisis Data Kualitatif Jakarta: UI Press

Moleong, Lexy J. 2010. Metodelogi Penelitian Kualitatif. Bandung: Remaja Rosdakarya Offset.

Muntasir, 2003. Tamiang Dalam Lintasan Sejarah. Banda Aceh: Yayasan Sri Ratu Syafiatun.

Simanjuntak, 2010. Melayu Pesisir Dan Batak Pegunungan (Orientasi Nilai Budaya). Jakarta: Yayasan Obor Indonesia.

Usman Abdul Rani,2003. Sejarah Peradapan Aceh (Suatu Analisis Interaksionis, Integrasi dan Konflik).Jakarta:Yayasan Obor Indonesia. 